\title{
Predatory hoverflies select their oviposition site according to aphid host plant and aphid species
}

\author{
Raki Almohamad, François J. Verheggen*, Frédéric Francis \& Eric Haubruge \\ Department of Functional and Evolutionary Entomology, Gembloux Agricultural University, Passage des Déportés 2, \\ B-5030 Gembloux, Belgium
}

Accepted: 19 April 2007

Key words: Episyrphus balteatus, oviposition behavior, Solanaceae, fitness, larval performance, Diptera, Syrphidae

\begin{abstract}
The hoverfly Episyrphus balteatus De Geer (Diptera: Syrphidae) is an abundant and efficient aphidspecific predator. Several aphidophagous parasitoids and predators are known to respond positively to aphid-infested plants. Semiochemicals from the latter association usually mediate predator/parasitoid foraging behavior toward sites appropriate for offspring fitness. In this study, we investigated the effect of aphid host plant and aphid species on foraging and oviposition behavior of E. balteatus. Behavioral observations were conducted using the Noldus Observer v. 5.0, which allows observed insect behavior to be subdivided into different stages. Additionally, the influence of aphid species and aphid host plant on offspring fitness was tested in a second set of experiments. Acyrthosiphon pisum Harris and Megoura viciae Buckton were equally attractive for E. balteatus whereas Aphis fabae Scopoli (all Homoptera: Aphididae) were less attractive. These results were correlated with (i) the number of eggs laid, which was significantly higher for the two first aphid species, and (ii) the fitness of hoverfly larvae, pupae, and adults. Two solanaceous plant species, Solanum nigrum L. and Solanum tuberosum L. (Solanaceae), which were infested with Myzus persicae Sulzer (Homoptera: Aphididae), were also compared using the same approach. Discrimination between these two M. persicae host plants was observed, with S. tuberosum being preferred as an oviposition site by the predatory hoverfly. Larval and adult fitness was correlated with the behavioral observations. Our results demonstrated the importance of the prey-host plant association on the choice of the oviposition site by an aphid predator, which is here shown to be related to offspring fitness.
\end{abstract}

\section{Introduction}

Natural enemies of herbivorous insects play an important role in the population dynamics of their prey (Price, 1987; Schoenly, 1990). In particular, the hoverfly, Episyrphus balteatus De Geer (Diptera: Syrphidae), is the most abundant in central Europe (Tenhumberg \& Poehling, 1991; Colignon et al., 2001) and one of the most efficient aphid-specific predators in natural agroecosystems, particularly with respect to cereal aphids (Entwistle \& Dixon, 1989; Tenhumberg \& Poehling, 1995). Because syrphid larvae have limited dispersal abilities (Chandler, 1969), the choice of the oviposition site has an important impact on offspring performance.

Host-finding behavior of stenophagous aphid predators and parasitoids has been investigated intensively (Godfray,

*Correspondence: E-mail: entomologie@fsagx.ac.be
1994; van Alphen \& Jervis, 1996). However, many of the recent studies were focused on coccinellids (Ferran \& Dixon, 1993; Sengonça \& Liu, 1994), while neglecting syrphids. Several factors were shown to impact the choice of the oviposition site for aphidophagous hoverflies: (i) the aphid species and their associated chemicals (Budenberg \& Powell, 1992; Bargen et al., 1998; Sadeghi \& Gilbert, 2000a,b); (ii) the host plant's physical and chemical characteristics associated with the aphid species (Dixon, 1958; Chandler, 1968a; Sanders, 1983; Vanhaelen et al., 2001); (iii) the aphid colony size and density (Kan, 1988; Scholz \& Poehling, 2000; Sutherland et al., 2001); and (iv) the age of the female (Sadeghi \& Gilbert, 2000c). Many semiochemicals, emitted either by prey or by their association with host plants, are presumed to play an important role in habitat selection by reducing the time needed for searching as well as increasing attack rates on prey (Dicke \& Sabelis, 1988; Vet \& Dicke, 1992). 
Most insect species, including predators (Hodek, 1993), show specific food resource preferences (Schoonhoven et al., 1998). Therefore, the correlation between adult preference for particular oviposition sites and subsequent larval performance has been extensively studied in phytophagous species (Harris et al., 2001; Forister, 2004). However, only a small proportion of these studies established a link between oviposition preference and larval performance (Thompson, 1988; Mayhew, 2001). Takeuchi et al. (2005) found that the phytophagous ladybird Epilachna admirabilis Crotch showed no preference between Trichosanthes cucumeroides Maxim and Gynostemma pentaphyllum Makino, even though the larvae performed better on the first plant species.

According to Gilbert (2005), there are few studies concerning the oviposition preference of female aphidophagous syrphids and larval performance towards different host plants or different aphid species. In this study, the oviposition behavior of E. balteatus was investigated for two host plants [Solanum tuberosum L. and Solanum nigrum L. (Solanaceae)] infested by one aphid species, Myzus persicae Sulzer (Homoptera: Aphididae), in a dual-choice experiment. Hoverfly fitness calculations for different aphid host plants were based on larval and adult performance (development and reproduction parameters) and were related to oviposition behavior. Additionally, similar experiments were conducted with three aphid species, Acyrthosiphon pisum Harris, Aphis fabae Scolpi, and Megoura viciae Bucton (all Homoptera: Aphididae), that infested Vicia faba L. (Leguminosae). Lastly, we investigated oviposition behavior and larval and adult performances.

\section{Materials and methods}

\section{Plant and insect rearing}

Broad beans ( $V . f a b a$ L.) and the two Solanaceae plants ( $S$. tuberosum L. and S. nigrum L.) were grown in $30 \times 20 \times 5 \mathrm{~cm}$ plastic trays filled with a mix of compost, perlite, and vermiculite (1:1:1) and maintained in controlled environment growth rooms (L16:D8 and $20 \pm 1^{\circ} \mathrm{C}$ ). Six-leaf solanaceous plants were used in the following experiments. Myzus persicae was reared on V. faba, S. tuberosum, and S. nigrum in separate controlled temperature rooms set at the same conditions as described above. The other aphid species, M. viciae, A. pisum, and A. fabae, were taken from stock cultures grown on $V$. faba. Adult E. balteatus were reared in $75 \times 60 \times 90 \mathrm{~cm}$ cages and were fed with bee-collected pollen, sugar, and water. Broad beans infested with $M$. viciae were introduced into the cages for $3 \mathrm{~h}$ every 2 days to allow oviposition. Hoverfly larvae were mass reared in aerated plastic boxes $(110 \times 140 \times 40 \mathrm{~mm})$ and were daily fed ad libitum with $M$. viciae as a standard diet.

\section{Oviposition preference}

Aphid host plant preference. In two-choice experiments, females were placed individually in net cages $(30 \times 30 \times$ $60 \mathrm{~cm}$ ) with two host plants infested with 400 M. persicae (M. persicae/S. tuberosum vs. M. persicae/S. nigrum). Their foraging behavior was then recorded for 10 min using the Observer ${ }^{\circledR}$ software (Noldus information Technology, version 5.0, Wageningen, The Netherlands). Descriptions of the four observed behavioral subdivisions are presented in Table 1. In similar two-choice experiments (M. persicael S. tuberosum vs. M. persicae/S. nigrum), a single E. balteatus female was allowed to lay eggs for $3 \mathrm{~h}$ and the number of eggs laid on each aphid host plant was counted. The experiments were conducted in a controlled temperature room at $20 \pm 1{ }^{\circ} \mathrm{C}$. Episyrphus balteatus females were approximately 20-30 days old and no induction of oviposition had been realized for $24 \mathrm{~h}$ prior to the experimentation. There were 10 replicates for each of the aforementioned experiments.

Aphid species preference. In similar two-choice experiments, a single E. balteatus female was placed in a cage with two

Table 1 Description of the behavioral events recorded for aphidophagous hoverfly Episyrphus balteatus exposed to different host plants of prey aphid

\begin{tabular}{lll}
\hline Observed behavior & & Description of behavior \\
\hline Immobility/cage & Predator immobilized on the cage & \\
Searching & Fly/cage & Predator fly in the cage \\
& Fly/plant & Predator fly near the plant \\
Acceptance of host plant & Immobile/plant & Predator landing on the plant \\
& Walking/plant & Predator moving on the plant \\
& Immobile proboscis/plant & Predator extends its proboscis and identifies the \\
& Walking proboscis/plant & stimulatory substrate to accept the host \\
Oviposition & Immobile abdomen/plant & Predator exhibits an abdominal protraction or oviposition \\
& Walking abdomen/plant & \\
& Egg laying & Oviposition \\
\hline
\end{tabular}


$V$. faba plants (with six leaves and $20 \mathrm{~cm}$ high), which were infested with different aphid species. Three combinations of aphids species were used (A. pisum vs. M. viciae, A. pisum vs. A.fabae, and M. viciae vs. A.fabae). By using the Observer ${ }^{\circledR}$ recorder, the behavioral subdivisions of the female hoverfly were recorded for $10 \mathrm{~min}$ and were observed to be identical to earlier tests (Table 1). In similar two-choice experiments (A. pisum vs. M. viciae, A. pisum vs. A. fabae, and $M$. viciae vs. A. fabae), a single E. balteatus female was allowed to lay eggs for $3 \mathrm{~h}$ and the number of eggs laid (oviposition rate) on each infested plant was counted. Experiments were conducted in a controlled temperature room at $20 \pm 1{ }^{\circ} \mathrm{C}$. Episyrphus balteatus females were approximately 20-30 days old and no induction of oviposition had been realized for $24 \mathrm{~h}$ prior to the experiment. Eight replicates for each pair of aphid species were performed.

\section{Larval performance}

Effect of aphid host plant. To assess the effect of aphid host plants on the fitness of E. balteatus, 30 newly emerged first instars were weighed and individually placed in plastic Petri dishes ( $9 \mathrm{~cm}$ in diameter). Each day, the larvae were fed an excess of $M$. persicae, which was taken from either of the host plants (S. tuberosum or S. nigrum). Hoverfly larvae were kept in an incubator at $20 \pm 1{ }^{\circ} \mathrm{C}$ and L16:D8, and the developmental time and survival rates were determined. The pupae and the adults were also weighed (using a Sartorius microbalance scale model Mc5) and placed, in male/female pairs, in $60 \times 30 \times 30 \mathrm{~cm}$ net cages. Fecundity and egg viability of female hoverflies were recorded daily during 3 weeks. Individual fitness (r) was calculated as a performance measure (McGraw \& Caswell, 1996) by integrating developmental time (D), survival $(\mathrm{m}=1$ or 0$)$, and potential fecundity using the equation: $r=[\operatorname{Ln}(\mathrm{m} \cdot \mathrm{V})] / \mathrm{D}$, where $\operatorname{Ln}$ is the natural logarithm.

Effect of aphid species. To assess the effect of the consumed aphid species on E. balteatus fitness, 30 newly emerged first instars were weighed and individually placed in plastic Petri dishes ( $9 \mathrm{~cm}$ in diameter). Each larva was fed an excess of each aphid species daily. This experiment was conducted with the three following aphid species: A. pisum, M. viciae, or A. fabae. The Petri dishes were kept in a controlled temperature room at $20 \pm 1{ }^{\circ} \mathrm{C}$ and L16:D8, and the developmental time and survival rates were determined. The pupae male/female the adults were also weighed and placed in male and female pairs in $60 \times 30 \times 30 \mathrm{~cm}$ net cages. Fecundity and viability of eggs were recorded daily during 3 weeks. Individual fitness ( $r$ ) was calculated as presented above (McGraw \& Caswell, 1996).

\section{Statistical analysis}

Means were compared using one-way analysis of variance (ANOVA) and Student's t-test or Tukey's test, conducted with Minitab ${ }^{\circledR}$ software (version 12.2, Minitab Inc, State College, PA, USA). Observed frequencies related to the adult emergence rates were compared to the corresponding frequencies from the control using $\chi^{2}$ tests. Percentage of mortality and egg viability were transformed using the angular transformation before ANOVA (arcsine $\sqrt{x}$; Dagnelie, 1973).

\section{Results}

\section{Oviposition preference}

Aphid host plant preference. In the dual-choice experiment, a significant preference of female hoverflies for the $M$. persicae-infested S. tuberosum was observed (Figure 1). Solanum tuberosum induced higher frequencies of acceptance (landing, walking, and proboscis extension) (Student's t-test: $\mathrm{t}=5.17, \mathrm{P}=0.001$ ) and oviposition (Student's t-test: $\mathrm{t}=-3.71, \mathrm{P}=0.005$ ) by the hoverfly.

In addition, the number of eggs laid by E. balteatus females was significantly affected by the aphid host plant species with $S$. tuberosum being significantly preferred as an oviposition site (Student's t-test: $\mathrm{t}=-3.54, \mathrm{P}=0.004$ ) (Figure 2).

Aphid species preference. Whereas no significant difference in terms of hoverfly acceptance behavior observed between A.pisum- and M. viciae-infested broad beans plants (Student's t-test: $\mathrm{t}=1.33, \mathrm{P}=0.226$ ), female hoverflies prefer and lay eggs on one of the two aforementioned aphid colonies rather than on A. fabae-infested plants

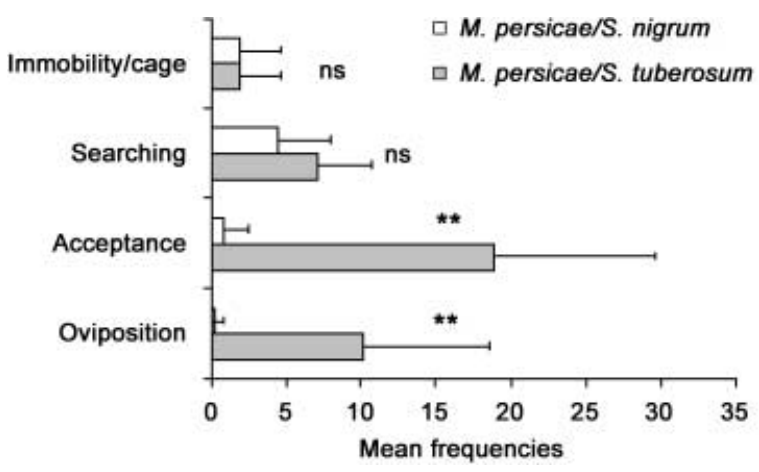

Figure 1 Behavioral observations (mean frequencies $+\mathrm{SD}$ ) on the oviposition pattern of Episyrphus balteatus females in relation to aphid host plants in two-choice experiment; ns and ${ }^{* *}$ indicate no significant and significant differences at $\mathrm{P}<0.01(\mathrm{n}=10)$. 


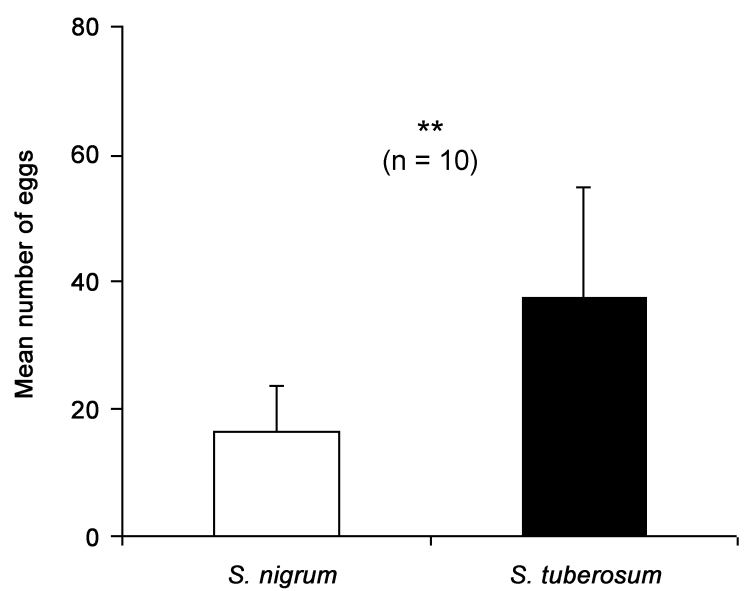

Figure 2 Effects of aphid host plants on oviposition rates (mean number of eggs $+\mathrm{SD}$ ) of Episyrphus balteatus in two-choice experiments after 3-h exposure with Myzus persicae as prey and Solanum nigrum and Solanum tuberosum as host plants. ${ }^{* *}$ indicates significant differences at $\mathrm{P}<0.01$.

(Figure 3). Female E. balteatus significantly preferred landing and laying eggs on $A$. pisum-infested broad beans rather than on the same host plant infested with $A$. fabae (Student's t-test: $\mathrm{t}=2.64, \mathrm{P}=0.033$ ). Megoura viciaeinfested broad beans were also significantly preferred to A. fabae-infested broad beans in terms of host-plant acceptance and oviposition site (Student's t-test: $t=3.62$, $\mathrm{P}=0.014)$.

These behavioral preferences were correlated with the number of observed eggs on the host plant of the aphid species (Figure 4). Similarly to the previously presented results, no significant preference was observed between $M$. viciae and A. pisum (Student's t-test: $\mathrm{t}=-0.47, \mathrm{P}=0.648$ ). These two aphid species corresponded with the more suitable species to induce egg oviposition by female hoverflies. Indeed, these females laid fewer eggs on A. fabae-infested broad beans than on M. viciae (Student's t-test: $\mathrm{t}=3.90$, $\mathrm{P}=0.001$ ) or A.pisum-infested plants (Student's t-test: $\mathrm{t}=6.22, \mathrm{P}<0.001)$.

\section{Larval performance}

Effect of aphid host plant. Several parameters concerning the larval, pupal, and adult development of E. balteatus have been compared for hoverflies fed with the same aphid species (M. persicae) but reared on two different host plants (S. tuberosum and S. nigrum) (Table 2). No difference in survival of larvae and adults was observed $\left(\chi^{2}=0.00\right.$, d.f. $=2, \mathrm{P}=1.00$ and $\chi^{2}=0.073$, d.f. $=2, \mathrm{P}=0.964$, respectively). However, larvae fed on $M$. persicae infesting $S$. tuberosum needed less time to reach the pupal stage $(\mathrm{t}=-3.95, \mathrm{P}<0.001)$. The resulting pupae were significantly heavier $(t=2.66, P=0.012)$, the time required to reach the
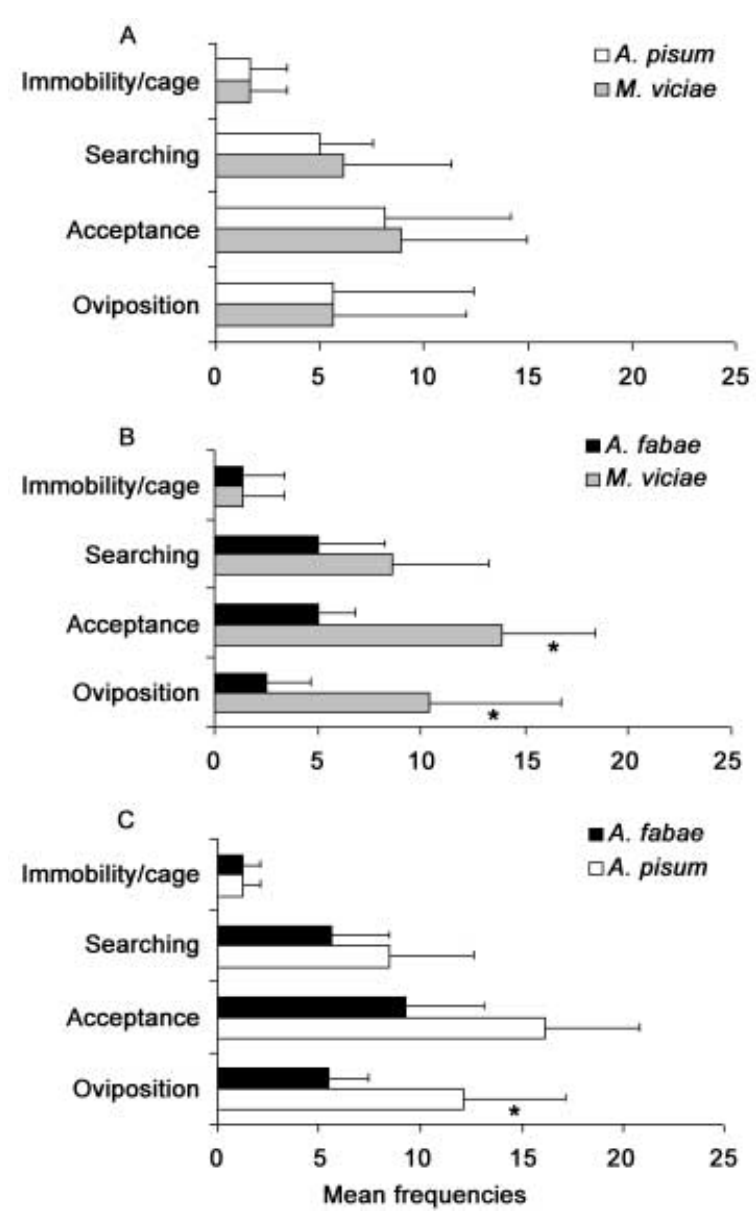

Figure 3 Behavioral observations (mean frequencies $+\mathrm{SD}$ ) on the oviposition pattern of Episyrphus balteatus adults in relation with aphid species in two-choice experiment; an * indicates significant differences at $\mathrm{P}<0.05(\mathrm{n}=10)$.

adult stage was significantly shorter $(\mathrm{t}=-4.32, \mathrm{P}<0.001)$, and no difference in adult weight was observed $(\mathrm{t}=1.82$, $\mathrm{P}=0.077$ ). Although hoverfly fecundity (eggs/female/day) and egg viability did not differ significantly according to solanaceous host plant $(\mathrm{t}=1.22, \mathrm{P}=0.223$ and $\mathrm{t}=0.29$, $\mathrm{P}=0.775$, respectively), hoverfly fitness ( $\mathrm{r}$ ) was significantly higher on $M$. persicae/S. tuberosum rather than on $M$. persicae/S. nigrum $(\mathrm{t}=2.45, \mathrm{P}=0.040)$.

Effect of aphid species. Differences in E. balteatus developmental parameters by aphid species (M. viciae, A. pisum, and A.fabae) were observed (Table 3 ) and E. balteatus larvae developed to maturity with each of the aphid species tested. Additionally, there was no significant difference in larval survival rates, which ranged from $73.33 \%$ for A. fabae to $80.00 \%$ for A. pisum. However, the aphid species significantly influenced the time needed for the larvae to 
Table 2 Effect of aphid host plant on development and reproductive performance of predatory hoverfly Episyrphus balteatus (mean \pm SD). Significant, grand significant differences, and high significant differences are at $\mathrm{P}<0.05, \mathrm{P}<0.01$, and $\mathrm{P}<0.001$, respectively

\begin{tabular}{lcclll}
\hline & \multicolumn{2}{l}{ Myzus persicae $/$ host plants } & & \\
\cline { 2 - 3 } Biological parameters & Solanum tuberosum & Solanum nigrum & & \multicolumn{2}{l}{ Test statistic } \\
\hline Larval development (day) & $7.75 \pm 0.79$ & $8.81 \pm 0.93$ & $\mathrm{t}=-3.95$ & $\mathrm{P}<0.001$ \\
Percentage of larval survival & 66.66 & 66.66 & & $\chi^{2}=0.00$, d.f. $=2$ & $\mathrm{P}=1.000$ \\
Percentage of survival (to adult emergence) & 63.33 & 66.66 & $\chi^{2}=0.07$, d.f. $=2$ & $\mathrm{P}=0.964$ \\
Pupal weight (mg) & $35.16 \pm 4.41$ & $31.06 \pm 0.93$ & $\mathrm{t}=2.66$ & $\mathrm{P}=0.012$ \\
Pupal development (day) & $7.53 \pm 0.51$ & $8.35 \pm 0.67$ & $\mathrm{t}=-4.32$ & $\mathrm{P}<0.001$ \\
Adult weight (mg) & $22.01 \pm 2.78$ & $20.46 \pm 2.53$ & $\mathrm{t}=1.82$ & $\mathrm{P}=0.077$ \\
Egg-to-adult development (day) & $18.74 \pm 1.66$ & $20.20 \pm 0.77$ & $\mathrm{t}=-3.50$ & $\mathrm{P}=0.002$ \\
Preoviposition duration & $9.66 \pm 2.81$ & $9.20 \pm 1.79$ & $\mathrm{t}=0.33$ & $\mathrm{P}=0.747$ \\
Fecundity (egg per female per day) & $30.83 \pm 31.25$ & $25.25 \pm 27.35$ & $\mathrm{t}=1.22$ & $\mathrm{P}=0.223$ \\
Percentage of total egg viability & $81.29 \pm 7.91$ & $80.93 \pm 5.24$ & $\mathrm{t}=0.29$ & $\mathrm{P}=0.775$ \\
Fitness (r) & $0.78 \pm 0.08$ & $0.65 \pm 0.09$ & $\mathrm{t}=2.45$ & $\mathrm{P}=0.040$ \\
\hline
\end{tabular}

reach pupal stage, where days required ranged from 8.85 (A. pisum) to 9.86 (A. fabae) $\left(\mathrm{F}_{2,65}=19.88, \mathrm{P}<0.001\right)$. The pupae on a diet of $A$. fabae were significantly lighter $\left(\mathrm{F}_{2,65}=8.55, \mathrm{P}=0.001\right)$ and needed more time to reach the adult stage $\left(\mathrm{F}_{2,65}=4.84, \mathrm{P}=0.011\right)$. In terms of the eggto-adult development time, the time required on A. fabae was significantly greater, reaching 17.81 days whereas only 15.5 days were needed for the individuals reared on A. pisum.

The fecundity (eggs/female/day) and egg viability were not significantly influenced by the aphid species $M$. viciae, A. pisum, and A. fabae $\left(\mathrm{F}_{2,221}=0.87, \mathrm{P}=0.419 ; \mathrm{F}_{2,157}=\right.$ $2.03, \mathrm{P}=0.135$, respectively). However, E. balteatus female fitness ( $\mathrm{r}$ ) was significantly higher on broad beans infested with A. pisum or M. viciae than on V. faba infested with A. fabae $\left(\mathrm{F}_{2,13}=4.69, \mathrm{P}=0.029\right)$.

\section{Discussion}

In this study, the effect of the aphid host plant variety on the choice of oviposition site by E. balteatus was clearly demonstrated. Sadeghi \& Gilbert (2000a,b) highlighted the ability of hoverflies to discriminate their potential oviposition sites, which consisted of aphid species and their associated host plant. However, these authors could not conclude whether the attraction and oviposition induction was due to the aphid species, the host plant, or the interaction of host plant and prey. Using the same aphid species (M. persicae), reared on both S. tuberosum and $S$. nigrum, we were able to compare the effect of the host plant on the oviposition site preference and hoverfly fitness. Indeed, S. tuberosum induced higher frequencies of acceptance and received more eggs from hoverfly females

Table 3 Influence of aphid species on various performance parameters of development of Episyrphus balteatus (mean \pm SD). Significant, grand significant differences, and high significant differences are at $\mathrm{P}<0.05, \mathrm{P}<0.01$, and $\mathrm{P}<0.001$, respectively

\begin{tabular}{|c|c|c|c|c|c|}
\hline \multirow[b]{2}{*}{ Biological parameters } & \multicolumn{3}{|c|}{ Aphid prey species } & \multirow[b]{2}{*}{ Test statistic } & \\
\hline & Megoura viciae & Acyrthosiphon pisum & Aphis fabae & & \\
\hline Larval development (day) & $9.17 \pm 0.39$ & $8.58 \pm 0.65$ & $9.86 \pm 0.91$ & $\mathrm{~F}_{2,65}=19.88$ & $\mathrm{P}<0.001$ \\
\hline Percentage of survival of larvae & 76.66 & 80.00 & 73.33 & $\chi^{2}=0.37$ & $\mathrm{P}=0.830$ \\
\hline Percentage of survival (to adult emergence) & 73.33 & 73.33 & 66.67 & $\chi^{2}=0.43$ & $\mathrm{P}=0.805$ \\
\hline Pupal weight (mg) & $31.82 \pm 3.55$ & $34.49 \pm 4.10$ & $29.69 \pm 4.03$ & $\mathrm{~F}_{2,65}=8.55$ & $\mathrm{P}=0.001$ \\
\hline Pupal development (day) & $7.09 \pm 0.41$ & $6.88 \pm 0.45$ & $7.29 \pm 0.46$ & $\mathrm{~F}_{2,65}=4.84$ & $\mathrm{P}=0.011$ \\
\hline Adult weight (mg) & $19.85 \pm 2.51$ & $22.45 \pm 3.55$ & $18.66 \pm 3.67$ & $\mathrm{~F}_{2,61}=7.45$ & $\mathrm{P}=0.001$ \\
\hline Egg-to-adult develoment (day) & $16.35 \pm 1.81$ & $15.50 \pm 0.72$ & $17.81 \pm 1.81$ & $\mathrm{~F}_{2,65}=18.14$ & $\mathrm{P}<0.001$ \\
\hline Preoviposition duration & $10.33 \pm 0.52$ & $9.20 \pm 1.30$ & $10.40 \pm 0.55$ & $\mathrm{~F}_{2,13}=3.25$ & $\mathrm{P}=0.072$ \\
\hline Fecundity (egg per female per day) & $32.11 \pm 32.75$ & $34.43 \pm 32.77$ & $27.06 \pm 36.02$ & $\mathrm{~F}_{2,221}=0.87$ & $P=0.419$ \\
\hline Percentage of total egg viability & $77.46 \pm 11.54$ & $72.79 \pm 10.60$ & $74.53 \pm 16.16$ & $\mathrm{~F}_{2,157}=2.03$ & $\mathrm{P}=0.135$ \\
\hline Fitness (r) & $0.66 \pm 0.06$ & $0.70 \pm 0.06$ & $0.58 \pm 0.08$ & $\mathrm{~F}_{2,13}=4.69$ & $\mathrm{P}=0.029$ \\
\hline
\end{tabular}



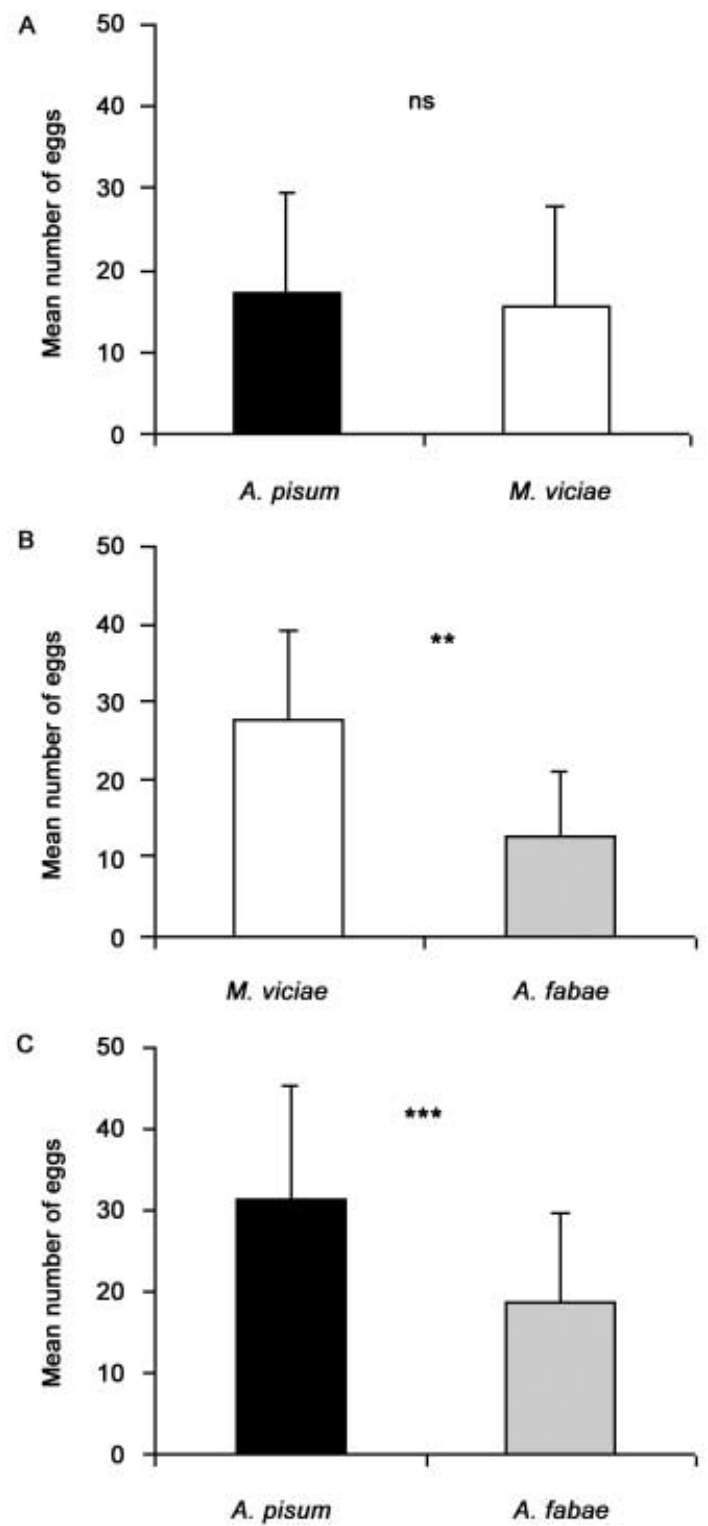

Figure 4 Effects of aphid species on oviposition rates (mean number of eggs $+\mathrm{SD}$ ) of Episyrphus balteatus in two-choice experiment after 3 -h exposure; ns, ${ }^{\star *}$, and ${ }^{* * *}$ indicate no significant and significant differences at $\mathrm{P}<0.01$ and $\mathrm{P}<0.001$, respectively. (A) Comparison between Acyrthosiphon pisum and Megoura viciae; (B) Comparison between $M$. viciae and Aphis fabae; and (C) Comparison between A. pisum and A. fabae $(\mathrm{n}=8)$.

than S. nigrum. In addition, the global hoverfly fitness was higher with $M$. persicae fed on S. tuberosum, confirming the hypothesis that ovipositing insects can select sites that improve the growth and survival of their offspring (Peckarsky et al., 2000). This should be even more true for insects that are unable to migrate easily from habitats poor in food, such as syrphid larvae. The reason behind the preference of E. balteatus for one plant rather than the other remains uncertain. When predators attempt to locate the prey habitat, they often use odors associated with prey presence, such as those from the herbivorous prey itself (Whitman, 1988), or from prey by-products, such as feces or honeydew (Budenberg \& Powell, 1992; Scholz \& Poehling, 2000; Francis et al., 2004). Moreover, predators can use volatiles that are produced by plants in response to herbivore damage, such as 'green' alcohols and aldehydes (Al Abassi et al., 2000; Francis et al., 2001). For example, Obata $(1986,1997)$ suggested that the Asian ladybird Harmonia axiridis Pallas was more strongly attracted to the odor of aphid-infested plants than to those of uninfested plants, and the volatile profiles of the two host plants are indeed different. Apart from the aphid-released (E)- $\beta$-farnesene, $S$. tuberosum release important amounts of the aphid alarm pheromone (Agelopoulos et al., 2000) whereas $S$. nigrum does not release this sesquiterpene (Schmidt et al., 2004). The (E)- $\beta$-farnesene was shown to attract predators such as E. balteatus (Francis et al., 2005a), which may explain the preference of female hoverflies for S. tuberosum. Plant color is one of the many stimuli used by herbivorous insects to recognize their host plant (Kelber, 2001). Sutherland et al. (1999) also demonstrated that aphid host plant color influenced the foraging behavior of the predatory hoverfly E. balteatus. However, this parameter could not explain the differences we obtained, as both plants (S. tuberosum and S. nigrum) were of similar color.

Our results also confirm the statement that hoverflies choose their oviposition site according to the infesting aphid species. Indeed, we demonstrated that $A$. fabae was not as attractive for E. balteatus as for A. pisum and M. viciae. Our data are also in accordance with those of Sadeghi \& Gilbert (2000a), who showed the pea aphid to be preferred among eight aphid species. However, M. viciae and A. fabae were not tested. The size of the aphid species tested might be a factor of importance in host selection. Indeed, similar numbers of aphids were tested, but whereas A. pisum and $M$. viciae are large aphids, A. fabae is slightly smaller and therefore represented less food for hoverfly offspring. The three tested aphid species release $(E)-\beta$ farnesene (Francis et al., 2005b) but might not release similar quantities, which could be specific or size dependent. The oviposition stimulus can also come from the aphid honeydew (Bargen et al., 1998; Scholz \& Poehling, 2000), which varies qualitatively and quantitatively from one species to another and during the season (Fischer \& Shingleton, 2001; Wool et al., 2006). Data vary from one predator to another. For example, even when reared on the same host plant ( $V . f a b a)$, the pea aphid (A. pisum) is considered suitable and the black bean aphid (A. fabae) is moderately 
suitable for larval development of the two-spotted ladybird Adalia bipunctata L. (Rana et al., 2002; Fréchett et al., 2006). However, the vetch aphid was found to be highly toxic for the same species (Fréchett et al., 2006).

The concordance between oviposition site selection and offspring performance is complex (Janz et al., 1994). Observed relationships between adult preference and some components of larval performance range from good concordance (Rausher, 1982; Singer, 1983) to poor concordance (Courtney, 1981). In some cases, poor concordance between preference and performance may result from oviposition onto introduced host plants (Chew, 1977; Legg et al., 1986) or relative rarity of the preferred host (Williams, 1983). Chandler (1968b) showed that the selection of an adequate oviposition site by syrphid females that lay eggs close to aphid colonies is essential to ensure the survival and fast development of their offspring. In our work, E. balteatus females demonstrated variations in their oviposition preference among the three tested aphids or among the two host plants and these differences had important consequences for the performance of their offspring.

\section{Acknowledgements}

The authors thank the government of Syria for financial support to Raki Almohamad. We are also grateful to Dr Yves Brostaux from the FUSAGx for his help with statistical analysis and to Adam Dellinger from Penn State University (State College, PA, USA) for the corrections he made to the manuscript. Our work has been funded by an FNRS (Fonds National de la Recherche Scientifique) grant (M 2.4.586.04.F).

\section{References}

Agelopoulos NG, Chamberlain K \& Pickett JA (2000) Factors affecting volatile emissions of intact potato plants, Solanum tuberosum: variability of quantities and stability of rations. Journal of Chemical Ecology 26: 497-511.

Al Abassi S, Birkett MA, Pettersson J, Pickett JA, Wadhams LJ \& Woodcock CM (2000) Response of the seven-spot ladybird to an aphid alarm pheromone and alarm pheromone inhibitor is mediated by paired olfactory cells. Journal of Chemical Ecology 26: 1765-1771.

van Alphen JJM \& Jervis MA (1996) Foraging behavior. Insect Natural Enemies (ed. by M Jervis \& N Kidd), pp. 1-62. Chapman \& Hall, London, UK.

Bargen H, Saudhof K \& Poehling HM (1998) Prey finding by larvae and adult females of Episyrphus balteatus. Entomologia Experimentalis et Applicata 87: 245-254.

Budenberg WJ \& Powell B (1992) The role of honeydew as an oviposition stimulant for two species of syrphids. Entomologia Experimentalis et Applicata 64: 57-61.
Chandler AEF (1968a) Some host-plant factors affecting oviposition by aphidophagous (Diptera: Syrphidae). Annals of Applied Biology 61: 415-423.

Chandler AEF (1968b) The relation between aphid infestations and oviposition by aphidophagous (Diptera: Syrphidae). Annals of Applied Biology 61: 425-434.

Chandler AEF (1969) Locomotive behavior of first instar larvae of aphidophagous Syrphidae (Diptera) after contact with aphids. Animal Behaviour 17: 673-678.

Chew FS (1977) Coevolution of pierid butterflies and their cruciferous food plants. II. The distribution of eggs on potential food plants. Evolution 31: 568-579.

Colignon P, Hastir P, Gaspar C \& Francis F (2001) Effet de l'environnement proche sur la biodiversité entomologique en culture maraichères de plein champ. Parasitica 56: 59-70.

Courtney SP (1981) Coevolution of pierid butterflies and their cruciferous foodplants. III. Anthocharis cardamines (L.). Survival, development and oviposition on different hostplants. Oecologia 51: 91-96.

Dagnelie P (1973) Théories et Méthodes Statistiques, tome 2. Presses Agronomiques, Gembloux, Belgique.

Dicke M \& Sabelis MW (1988) Infochemical terminology: based cost-benefit analysis rather than origin of compounds? Functional Ecology 2: 131-139.

Dixon AFG (1958) The escape responses shown by certain aphids to the presence of the coccinellid Adalia decempunctata (L.). Transactions of the Royal Entomological Society of London 110: 319-334.

Entwistle JC \& Dixon AFG (1989) The effect of augmenting grain aphid (Sitobium avenae) numbers in a field of winter wheat in spring on the aphids abundance in summer and its relevance to the forecasting of outbreaks. Annals of Applied Biology 114: 397-408.

Ferran A \& Dixon AFG (1993) Foraging behavior of ladybird larvae (Coleoptera: Coccinellidae). European Journal of Entomology 90: 383-402.

Frechette B, Dixon AF, Aluazet C, Boughenou N \& Hemptinne JL (2006) Should aphidophagous ladybirds be reluctant to lay eggs in the presence of unsuitable prey? Entomologia Experimentalis et Applicata 118: 121-127.

Fischer MK \& Shingleton AW (2001) Host plant and ants influence the honeydew sugar composition of aphids. Functional Ecology 15: 544-550.

Forister ML (2004) Oviposition preference and larval performance within a diverging lineage of lycaenid butterflies. Ecological Entomology 29: 264-272.

Francis F, Lognay G, Gaspar C \& Haubruge E (2004) Olfactory responses to aphids and host plant volatile releases: $(E)-\beta$ farnesene an effective allomone for the predator Adalia bipunctata. Journal of Chemical Ecology 30: 741-755.

Francis F, Lognay G, Wathelet JP \& Haubruge E (2001) Effects of allelochemicals from first (Brassicaceae) and second (Myzus persicae \& Brevicoryne brassicae) trophic levels on Adalia bipunctata. Journal of Chemical Ecology 27: 243-256.

Francis F, Martin T, Lognay G \& Haubruge E (2005a) Role of (E)$\beta$-farnesene in systematic aphid prey location by Episyrphus 
balteatus larvae (Diptera: Syrphidae). European Journal of Entomology 102: 431-436.

Francis F, Vandermoten S, Verheggen F, Lognay G \& Haubruge E (2005b) Is the (E)- $\beta$-farnesene only volatile terpenoid in aphids? Journal of Applied Entomology 129: 6-11.

Gilbert F (2005) Syrphid aphidophagous predators in a foodweb context. European Journal of Entomology 102: 325333.

Godfray HCJ (1994) Parasitoids Behavioral and Evolutionary Ecology. Princeton University Press, Princeton, NJ, USA

Harris MO, Ndanayaka M \& Griffin W (2001) Oviposition preferences of the Hessian fly and their consequences for the survival and reproductive potential of offspring. Ecological Entomology 26: 473-486.

Hodek I (1993) Habitat and food specificity in aphidophagous predators. Biocontrol Science and Technology 3: 91-100.

Janz N, Nylin S \& Wedell H (1994) Host plant utilization in the Comma butterfly: source of variation and evolutionary implications. Oecologia 99: 132-140.

Kan E (1988) Assessment of aphid colonies by hoverflies. I. Maple aphids and Episyrphus balteatus (de Geer) (Diptera: Syrphidae). Journal of Ethology 6: 39-48.

Kelber A (2001) Receptor based models for spontaneous colour choices in flies and butterflies. Entomologia Experimentalis et Applicata 99: 231-244.

Legg DE, Schenk TC \& Chiang HC (1986) European corn borer (Lepidoptera: Pyralidae) oviposition preference and survival on sunflower and corn. Environmental Entomology 15: 631634.

Mayhew PJ (2001) Herbivore host choice and optimal bad motherhood. Trends in Ecology and Evolution 16: 165-167.

McGraw JB \& Caswell H (1996) Estimation of individual fitness from life-history data. American Naturalist 147: 47-64.

Obata S (1986) Mechanism of prey finding in the aphidophagous ladybird beetle Harmonia axyridis (Coleoptera: Coccinellidae). Entomophaga 31:303-311.

Obata S (1997) The influence of aphids on the behavior of adults of the ladybird beetle Harmonia axyridis (Coleoptera: Coccinellidae). Entomophaga 42: 103-106.

Peckarsky BL, Taylor BW \& Caudill CC (2000) Hydrologic and behavioral constraints on oviposition of stream insects: implications for adult dispersal. Oecologia 125: 186-200.

Price PW (1987) The role of natural enemies in insect populations. Insect Outbreaks (ed. by P Barbosa \& JC Schultz), pp. 287312. Academic Press, London, UK.

Rana JS, Dixon AFG \& Jarosik K (2002) Costs and benefits of prey specialization in a generalist insect predator. Journal of Animal Ecology 71: 15-22.

Rausher MD (1982) Population differentiation in Euphydryas editha butterflies: larval adaptation to different hosts. Evolution 36: 581-590.

Sadeghi H \& Gilbert F (2000a) Oviposition preferences of aphidophagous hoverflies. Ecological Entomology 25: 91-100

Sadeghi H \& Gilbert F (2000b) Aphid suitability and its relationship to oviposition preference in predatory hoverflies. Journal of Animal Ecology 69: 771-784.

Sadeghi H \& Gilbert F (2000c) The effect of egg load and host deprivation on oviposition behaviour in aphidophagous hoverflies. Ecological Entomology 25: 101-108.

Sanders W (1983) The searching behaviour of gravid Syrphus corollae Fabr. (Diptera: Syrphidae) and its depending on optical cues [In German]. Zeitschrift für Angewandte Zoologie 70: 235-247.

Schmidt D, Kessler A, Kessler D, Schmidt S, Lim M et al. (2004) Solanum nigrum: a model ecological expression system and its tools. Molecular Ecology 13: 981-995.

Schoenly K (1990) The predators of insects. Ecological Entomology 15: 333-345.

Scholz D \& Poehling HM (2000) Oviposition site selection of Episyrphus balteatus. Entomologia Experimentalis et Applicata 94: 149-158.

Schoonhoven LM, Jermy T \& Van Loon JJA (1998) Insect Plant Biology. Chapman \& Hall, London.

Sengonça C \& Liu B (1994) Responses of the different instar preadtor, Coccinella septempunctata L. (Coleoptera: Coccinellidae), to kairomone produced by prey and non-prey insects as well as the predator itself. Zeitschrift für Planzenkrankeiten und Pflazenschutz 101: 173-177.

Singer MC (1983) Determinants of multiple host use by a phytophagous insect population. Evolution 37: 389-403.

Sutherland JP, Sullivan MS \& Poppy GM (1999) The influence of floral character on the foraging behaviour of the hoverfly, Episyrphus balteatus. Entomologia Experimentalis et Applicata 93: $157-164$.

Sutherland JP, Sullivan MS \& Poppy GM (2001) Oviposition behaviour and host colony size discrimination in Episyrphus balteatus (Diptera: Syrphidae). Bulletin of Entomological Research 91: 411-417.

Takeuchi M, Kishikawa H \& Tamura M (2005) Host use in relation to food availability and larval development in the specialist herbivore Epilachna admirabilis (Coleoptera: Coccinelidae). Applied Entomology and Zoology 40: 177-184.

Tenhumberg B \& Poehling HM (1991) Studies on the efficiency of syrphid larvae, as predators of aphids on winter wheat. Behaviour and Impact of Aphidophaga (ed. by L Polgar, RJ Chambers, AFG Dixon \& I Hodek), pp. 281-288. SPB Academic Publishing BV, The Hague, The Netherlands.

Tenhumberg B \& Poehling HM (1995) Syrphids as naturals enemies of cereal aphids in Germany: aspects of their biology and efficacy in different years and regions. Agriculture, Ecosystems and Environment 52: 39-43.

Thompson JN (1988) Evolutionary ecology of the relationship between oviposition preference and performance of offspring in aphidophaous insects. Entomologia Experimentalis et Applicata 47: 3-14.

Vanhaelen N, Haubruge E, Gaspar C \& Francis F (2001) Oviposition preferences of Episyrphus balteatus. Faculteit Landbouwkundige en Toegepaste Biologische wetenschappen. Universiteit Gent 66/2a: 269-275.

Vet LEM \& Dicke M (1992) Ecology of infochemical use by natural enemies in a tritrophic context. Annual Review of Entomology 37: 141-172.

Whitman DW (1988) Allelochemical interactions among plants, herbivores, and their predators. Novel Aspects of Insect-Plant 
Interactions (ed. by P Barbosa \& DK Letourneau), pp. 11-64. Wiley, New York.

Williams KS (1983) The coevolution of Euphydryas chalcedona butterflies and their larval host plants. III. Oviposition behavior and host plants quality. Oecologia 56: 336-340.
Wool D, Hendrix DL \& Shukry O (2006) Seasonal variation in honeydew sugar content of galling aphids (Aphidoidea: Pemphigidae: Fordinae) feeding on Pistacia: host ecology and aphid physiology. Basic and Applied Ecology 7: 141151. 